\title{
CIRRHOTIC PORTAL HYPERTENSION: NEW INSIGHTS IN AN OLD SYNDROME
}

\section{Priscila Pollo-Flores}

Docente adjunto do Departamento de Medicina Clínica Hepatologia; Doutorado Clínica Médica pela Universidade Federal do Rio de Janeiro - UFRJ, Brasil.

E-mail: priscilapollo96@gmail.com

\section{Mônica Soldan}

Doutora em Engenharia Biomédica pela Universidade Federal do Rio de Janeiro - UFRJ, Brasil. Médica do Serviço de Gastroenterologia, Hospital Universitário Clementino Fraga Filho, Rio de Janeiro (RJ), Brasil.

\section{Guilherme Ferreira da Motta Rezende}

Docente associado do Departamento de Clínica Médica Serviço de Hepatologia Setor de Hemodinâmica Hepática; Doutorado no Hospital Paul-Brousse em Paris, França.

\begin{abstract}
Liver Cirrhosis is currently understood as a pathological systemic process, inflammatory, vascular and, overall, dynamic and bidirectional. The intrahepatic circulation is the site of pronounced and determinant alterations characterized by the increase of mechanical resistance to the portal blood flow and the increase of the hepatic vascular tone. Compensated cirrhosis and decompensated cirrhosis can be described according to the presence and severity of portal hypertension. The most accurate method for diagnosis and stratification of portal hypertension is the measurement of the hepatic venous pressure gradient (HVPG). The standard pharmacological treatment available for cirrhotic portal hypertension consists, currently in the use of a non-selective beta-blocker(NSBB). A significant proportion of patients do not respond to treatment. Moreover, it seems to be a therapeutic window of the non-selective beta blockers in which very early stages of compensated cirrhosis and decompensated patients are not benefiting from that medication. The discovery of new drugs that might interfere in the disease's evolution and treat portal hypertension, allows a glimpse of a new horizon in hepatic cirrhosis.
\end{abstract}

KEY WORDS: Cirrhotic Portal Hypertension; Pharmacological Therapy; Hepatic Venous Pressure Gradient.

\section{HIPERTENSÃO PORTA CIRRÓTICA: NOVAS PERSPECTIVAS SOBRE UMA SÍNDROME ANTIGA}

RESUMO: A cirrose Hepática é, atualmente, compreendida como um processo patológico sistêmico, inflamatório, vascular e, em geral, dinâmico e bidirecional. A circulação intra-hepática é o local de alterações pronunciadas e determinantes, caracterizadas pelo aumento da resistência mecânica ao fluxo sanguíneo portal e pelo aumento do tónus vascular hepático. A cirrose compensada e a descompensada podem ser descritas de acordo com a presença e gravidade da hipertensão porta. O método mais preciso para o diagnóstico e estratificação da hipertensão porta é a medida do gradiente de pressão venosa hepática (HVPG). O tratamento farmacológico disponível para a hipertensão porta cirrótica, nos dias atuais, consiste na utilização de um beta bloqueador não seletivo (NSBB). Uma proporção significativa dos pacientes não responde ao tratamento. Além disso, parece haver uma janela terapêutica dos beta-bloqueadores não seletivos, em que fases muito iniciais da cirrose compensada e pacientes descompensados não se beneficiam da medicação. Logo, a descoberta de novas drogas que possam interferir na evolução da doença e tratar a hipertensão porta, permite vislumbrar um novo horizonte na cirrose hepática.

PALAVRAS-CHAVE: Hipertensão Porta Cirrótica; Tratamento Farmacológico; Gradiente de Pressão Venosa Hepatica. 


\section{INTRODUCTION}

Pathophysiology of hepatic cirrhosis is complex and involves multiple steps. The Hepatic Stellate Cell (HSC), when activated is capable of producing extracellular matrix quantitatively and qualitatively altered, featuring the process of fibrogenesis (Picture 1). The transdifferentiation of the HSC in myofibroblast occurs, and these cells show an increase of gene expression of the transformation growth factor beta (TGF beta) and platelet derived growth factor (PDGF)(IWAKIRI, 2012). The Stellate cell, while active, presents less response to vasodilators such as nitric oxide and suffers the action of endothelin 1, which is found increased in hepatic cirrhosis, leading to vasoconstriction (IWAKIRI, 2014).

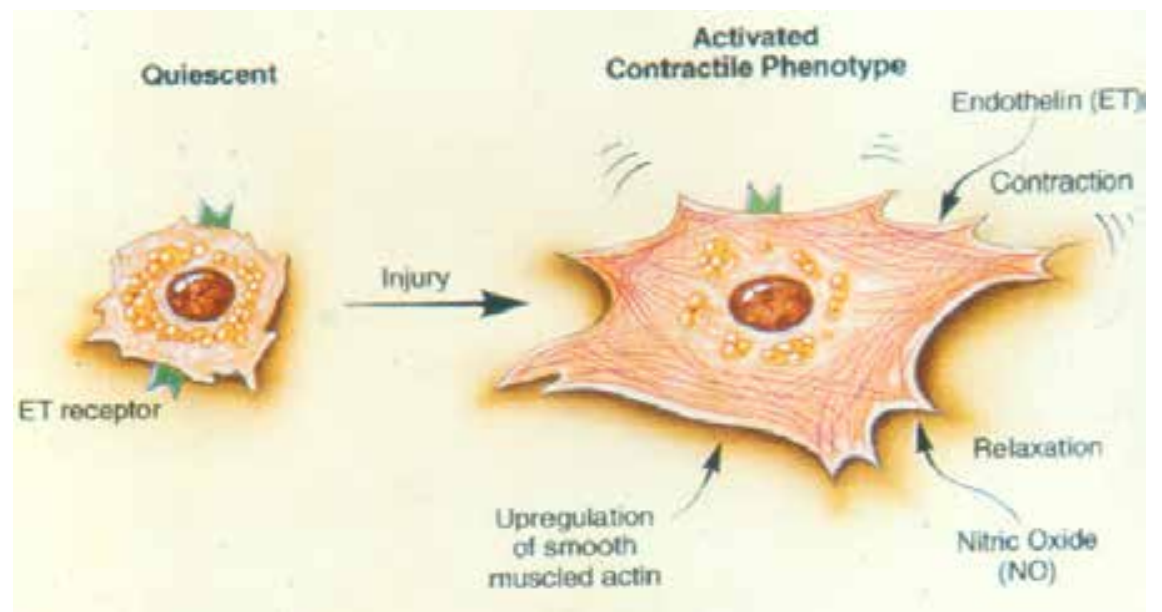

Picture 1. Hepatic Stellate Cell activation (SHERLOCK et al., 2011).

Capillarization of sinusoids (picture 2) that lose their fenestrations increasing mechanically the vascular resistance besides harming the transport of sinusoid solutes to the hepatocytes (MCGUIRE; BISSELL et al., 1992 ) is an important feature of portal hypertension $(\mathrm{PH})$. Angiogenesis is also present and stimulated by angiopoetin, vascular endothelium growth factor (VEGF) and platelet derived growth factor (PDGF). Inflammation is intimately related to angiogenesis as shown in other pathologies, having seen diabetes mellitus and atherosclerosis (ARROYO; IRUELA-ARISPE, 2010). Liver sinusoidal endothelial cells (LSEC) express molecules like "toll-like 4", (TLR4), an endotoxin receptor that regulates angiogenic response. That way, as the first cells to be exposed to the portal vein lipopolysaccharide (LPS), angiogenesis is mediated through TLR4/MyD88 resulting in fibrosis and portal hypertension (THABUT; TAZI et al., 2007; JAGAVELU; ROUTRAY et al., 2010). 


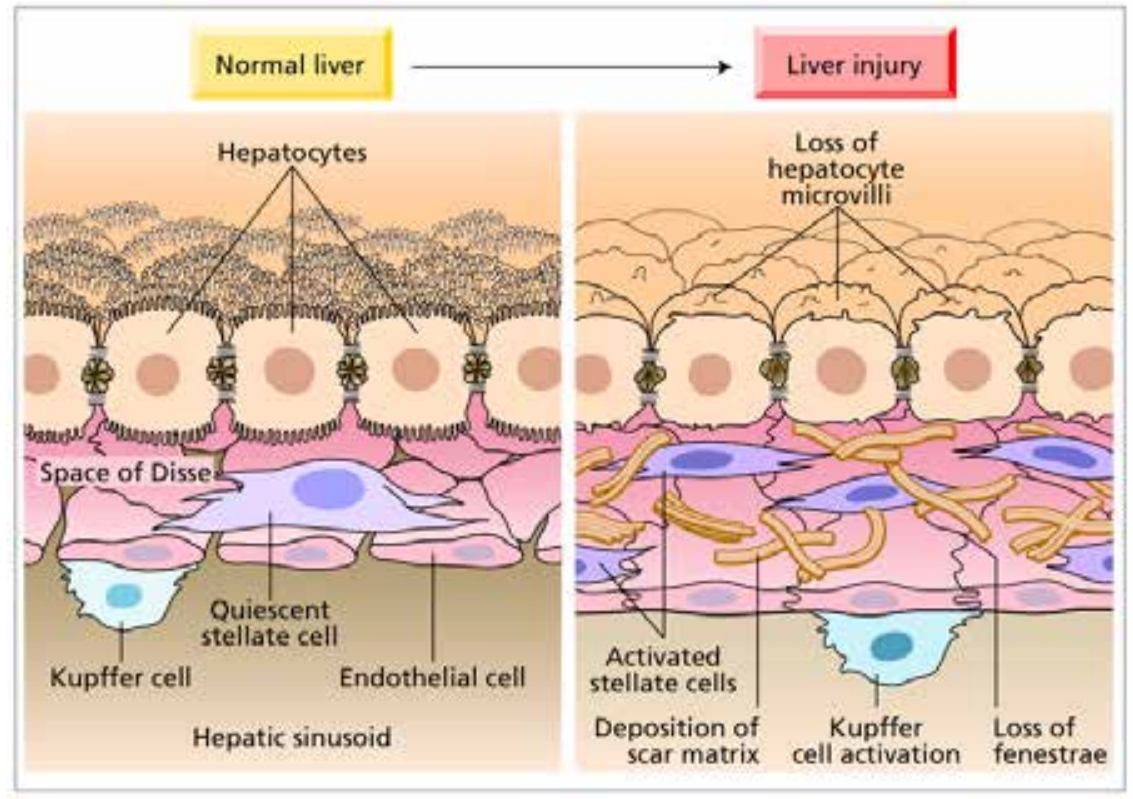

Picture 2. capillarization of hepatic sinusoids in Disse's space (SHERLOCK'S et al,2011)

In the hepatic sinusoids, the oxidative stress is characterized by the increase of production of superoxide radicals, which react with the nitric oxide (NO) forming peroxynitrite(ONOO-) decreasing the bioavailability in the hepatic circulation of NO. The decreased activity of superoxide dismutase, an enzyme responsible of eliminating free radicals, contributes to the increase of reactive oxygen species (ROS) on cirrhotic livers.

The oxidative stress interferes in the activity of the endothelial synthase of $\mathrm{NO}$ (eNOS) in three manners: increasing the association of eNOs with caveolin-1, inhibitor of eNOS activity; inhibiting of phosphorylation eNOS induced by endothelin and increasing the dissociation of eNO of the B-endothelin receptor. Along with that, NO is decreased setting up a feature of endothelial dysfunction (IWAKIRI, 2012).

Although eNOs is not decreased in the intrahepatic environment, there is a reduction in its activity. This change is given to post-translational effects. In cirrhosis, it is known that there is a "downregulation" in the activity of eNOs due to the increase of interaction of eNOs with the inhibiting protein caveolin-1 (SHAH; TORUNER et al. 1999).

Thromboxane A2 (TxA2), a potent vasoconstricting molecule, is generated by the action of cyclooxygenase 1 (COX-1) in hepatic endothelial cells. In a cirrhotic liver, the production of TxA2 is increased by the Liver Sinusoidal Endothelial Cells (LSEC) and contributes to the increase of intrahepatic resistance (RVIH) (IWAKIRI, 2014).

Knowledge of the reversible compound of portal hypertension indicated by the increase of the vascular tone allowed the use of vasodilators in this syndrome. There is an unbalance between vasodilators and vasoconstrictors. Consequently, the increase of intrahepatic nitric oxide is a rational therapeutic measure, and in current investigation. This compound in Portal Hypertension is responsible for $30 \%$ of increase in intrahepatic resistance and many studies have focused in the reversibility of these factors (BOSCH, 2007).

The evolution process of hepatic cirrhosis and portal hypertension is dynamic and includes successive states with very different prognosis connotations as shown in D'Amico and cols classification (RIPOLL; GROSZMANN et al., 2007; RIPOLL, 2007). Clinically significative portal hypertension, CSPH, defined by HVPG above $10 \mathrm{mmHG}$, is an important predictive factor of decompensation, appearance of hepatocellular carcinoma (HCC), death and also related to therapeutic response (BERZIGOTTI, 2008; ZIPPRICH; GARCIA-TSAO et al., 2012; VOROBIOFF; GROZMANN, 2015). Those patients with a GPVH between $5 \mathrm{mmHg}$ and $10 \mathrm{mmHg}$, non-clinically significative portal hypertension, should have optimize ethiology treatment to avoid disease progression. Non-Clinically significative Portal Hypertension (NCSPH) depends of intrahepatic factors and this should, then, be the 
therapeutically targets. Concomitantly and theoretically, the hemodynamic profile of patients with a GPVH $<10$ $\mathrm{mmHg}$ is very close to normal and hyperdinamic syndrome does not predominate (VOROBIOFF; GROSZMANN, 2015). Behavioural measures may interfere in the course of portal hypertension such as weight loss decrease. Studied dietetic measures like dark chocolate, caffeine and antioxidants may be interesting and studies show decrease in Portal Hypertension(BERZIGOTTI; BOSCH, 2014).

Splanchnic and systemic vasodilation is responsible for the hyperdynamic circulation which presents many mediators like glucagon, prostacyclin (PGI2), nitric oxide and Vascular Endothelium Growth Factor (VEGF). The circulatory dysfunction presents with an activation of the renin angiotensin aldosterone systems, sympathetic nervous system and antidiuretic hormone (MOORE; WONG et al., 2003, SOLA; GINES, 2010). Inflammatory cytokines, VEGF and mechanical forces such as shear stress are also important steps that activate AKT, "Heatshock 90" protein (HSP 90) and eNOs. Bacterial translocation from the intestine to mesenteric lymph nodes is another mechanism increasing alpha tumor necrosis factor, contributing to the increase of systemic nitric oxide. These derrangements culminates in hepato-renal syndrome and hyponatremia. (GARCIATSAO; FRIEDMAN et al., 2010; ARROYO; GINES et al., 1996).

Splanchnic vasodilation may be treated through splanchnic vasoconstrictors. Chronically, non-selective betablockers have shown themselvescapable ofdecreasing portal hypertension and acutely vasopressin, somatostatin and synthetic analogue, especially terlipressin also work effectively. Other drugs for isolated or combined use, in particular or general situations, may be useful, such as midodrine, alpha 1 adrenergic agonists, acting in arteries and veins, effective in the reduction of manifestations of circulatory dysfunction related to ascites, contributing to clinical and hemodynamic improvement (BERZIGOTTI; BOSCH, 2014; BOLOGNESI; DI PASCOLI et al., 2014).

Lebrec and collaborators have described the effects of beta-blockers in the decrease of portal hypertension and rebleeding related to portal hypertension (LEBREC; NOUEL et al., 1980; LEBREC, POYNARD et al., 1981). Since then, beta blockers are the drug of choice in the chronic treatment of portal hypertension. Non Selective beta blockers are capable of decreasing the incidence of digestive bleeding and reducing mortality, decreasing bleeding and rebleeding in $20 \%$ of patients in primary and secondary prophylaxis, besides decreasing mortality (CHENG; ZHU et al., 2003). The effect over beta receptors 2 is more important and significative in chronic and continous use of BBNS (BOSCH; BERZIGOTTI et al., 2008). Between other benefits of the use of the beta blockers are included also the decrease of time of intestine transit, reducing bacteria supergrowth and the risk of translocation (TSOCHATZIS; BOSCH et al., 2012). GPVH reduction through beta blockers is about $15 \%$ and only $37 \%$ of patients are hemodynamic responders (OPIO; GARCIA-TSAO 2011).

Carvedilol is emerging as primary bleeding prophylaxis drug and seems more effective than the elastic banding of esophageal varices (BEV) as like propranolol. The effect of carvedilol is similar to the propranolol or nadolol associated to prazosin and more potent (16\%-43\% vs pre-treatment values) compared to isolated propranolol or nadolol $(12 \%-13 \%$ vs pretreatment values) (BANARES; MOITINHO et al., 2002). Carvedilol achieves a good hemodynamic response in more than $50 \%$ of patients non-responder to propranolol (REIBERGER; ULBRICH et al., 2013; GONZALEZ; ZAMORA et al., 2008; GARCIA-TSAO; BOSCH, 2010).

\section{METHODOLOGY}

Research of articles in PUBMED databasis was conducted using the following search terms : cirrhotic portal hypertension; pharmacological therapy; hepatic venous pressure gradient measure (HVPG) and statins in portal hypertension. Inclusion criteria were grounded in the relevance of the articles for the purpose of the review ( publications from highly specialized centers, randomized controlled trials, basic research).

\subsection{NEW PHARMACOLOGICAL THERAPIES}

The intention of expansion of the therapy arsenal, the focus of research was moved beyond splanchnic vasoconstrictors in the sense of potential 
modification of Intrahepatic Vascular Resistance (IHVR), acting in many levels of physiopathogeny in $\mathrm{PH}$ as in picture 3 . This change is well sustained once besides improving Portal Hypertension directly, also can act in perfusion and, consequently, liver functions. The scientific interest related to the functional component of IHVR, which seems to be target of future pharmacological interventions, has grown and become more attractive. This augmented IHVR derives from already discussed complex mechanisms(VERBEKE; FARRE et al., 2014).

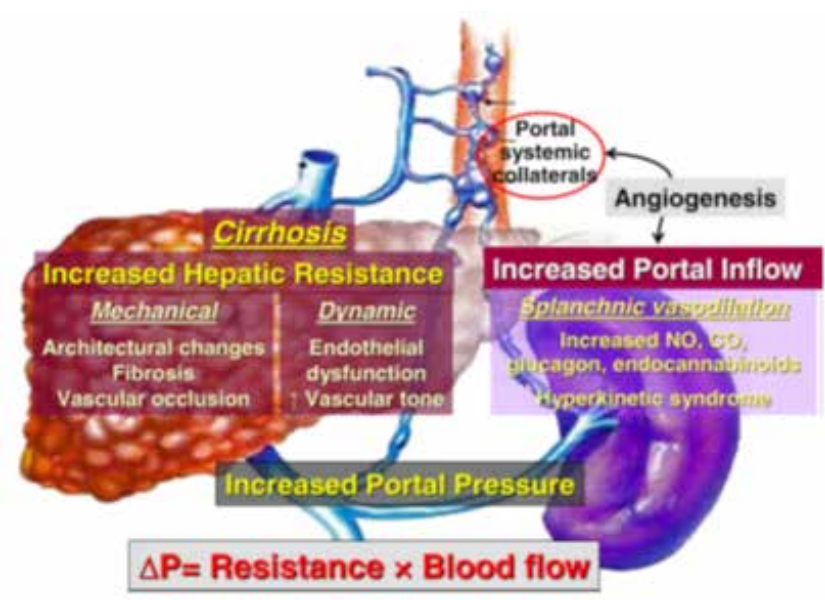

Picture 3. Pathophysiology in portal Hypertension and possible therapeutic targets (BOSCH et al., 2008)

Drugs with an anti-oxidative stress effect, such as ascorbic acid-Vitamin C - are potent natural antioxidants that are found lacking in hepatic cirrhosis (VERBEKE; FARRE et al., 2014). Tetrahydrobiopterin, responsible cofactor to regulate eNOS activity, is capable of increasing availability of $\mathrm{ON}$ and is found diminished in in hepatic cirrhosis and studies with supplementation have already been done with optimistic results (MATEI; RODRIGUEZVILARRUPLA ET AL., 2006; MATEI; RODRIGUEZVILARRUPLA et al., 2008). Superoxide dismutase (SOD) is an enzyme that catalyses free radicals of oxygen generated in oxidative stress and is also found less in cirrhosis. Transfer of genes from SOD in animal models has shown to reduce portal hypertension (LAVINA; GRACIASANCHO et al., 2009; GARCIA-CALDERO; RODRIGUEZVILARRUPLA et al., 2011). Fenofibrate acts through the activated proliferative peroxissome alpha receptor (PPAR alpha) inducing the same which increases gene transcription changing the vascular tone, fibrogenesis and oxidative stress(RODRIGUEZ-VILARRUPLA; LAVINA et al., 2012).
Resveratrol is naturally found in nuts and other fruits with anti-inflammatory properties, vascular endothelium protectors, antiplatelets, and antioxidants(DI PASCOLI; DIVI et al., 2013). Coffee, another natural product, has an antifibrotic action, which was recently described and patients should be advised to include that in their diet (BERZIGOTTI; BOSCH, 2014). In the same way, foods with antioxidant properties such as dark chocolate present potential benefit of increasing ON availability and reducing PH (BERZIGOTTI; BOSCH, 2014)).

Drugs with an effect in COX-1, inhibiting the potent vasoconstrictor thromboxane $\mathrm{A} 2$, decrease portal hypertension(ROSADO; RODRIGUEZ-VILARRUPLA et al., 2013) in animal models, like Terutroban, but present many deleterious effects on other organs and systems stopping its practical use.

Antibiotics, like rifaximin, are largely used in gastroenterology and hepatology, and present action only in gastrointestinal tract doing intestinal decontamination and lowering endotoxemia levels, with a related decrease of GPVH. There is still another target of research development, in the field of collateral formation and neoangiogenesis stimulated by VEGF and PEGF (BOSCH; ABRALDES et al., 2010), and, its antagonists look to decrease $\mathrm{PH}$ lowering splanchnic vasodilation and formation of portosystemical collateral vessels. Sorafenib, a multikinase inhibitor, has already been used in the context of hepatocellular carcinoma but its severe and frequent adverse events limit its clinical applicability.

Vasodilators like nitrates, prazosin, clonidine, angiotensin blockers and angiotensin converting enzyme blockers resulted in a significative decrease of about $17 \%$ in HVPG but do not have selectivity. The systemic effect of vasodilation is poorly tolerated and frequently leads to the drug suspension. Other tested therapies for portal pressure reduction were NCX-1000, selective donors of nitric oxid to the liver also decreased intrahepatic resistance in models of biliary cirrhosis and made by CCL4(ZAFRA; ABRALDES et al., 2004; ABRALDES; RODRIGUEZ-VILARRUPLA et al., 2007), and simvastatin with an increased post translational regulation of nitric oxid synthase. In a clinical essay, simvastatin has shown GPVH decrease in a 32\% of patients(ABRALDES; ALBILLOS 
et al., 2009). The effect magnitude was moderated, with a decrease of $10 \%$ in $40 \%$ of the patients and $\geq 20 \%$ or $<12 \mathrm{mmHg}$ in a third of the patients. The effect was also evidenced in the group in use of BBNS being able to increase the number of responders to these drugs. The effect of GPVH reduction was concomitant with the effective improvement of hepatic perfusion and hepatic function (mechanism evaluated through indocyanine green) (ABRALDES; ALBILLOS et al., 2009).

Recently, the agonist farnesoid $\mathrm{X}$ receptor, obeticolic acid (FXR; NR1H4), have shown effects in many hepatic and gastrointestinal pathologies with the potential of regulating the intrahepatic vascular tone. Verbeker and collaborators have shown that in models of hepatic cirrhosis in rats, there is a deficiency of FXR and its restoration improves $\mathrm{PH}$ decreasing $\mathrm{RVIH}$ without important deleterious hemodynamic effects (VERBEKE; FARRE et al., 2014).

Statins are drugs with the potential to act only in intrahepatic circulation increasing the availability of ON. Inhibitors of 3-hydroxy-3-methylglutaryl coenzyme A reductase are drugs developed to reduce cholesterol that have pleiotropic effects. These reduce oxidative stress and inflammation in vessel walls, having antithrombotic properties and improve endothelial function, increasing ON production by endothelial cells. Statins act in the dynamic and reversible component of PH (RAMIREZ; BRICENO et al., 2012).

Increase in the production of NO is mediated by the activation of kinase protein AKT dependent of phosphatidyl inositol-3 kinase leading to phosphorylation of endothelial ON synthase in Ser1177 which induces the increase of the eNOS function (ZAFRA; ABRALDES et al., 2004). There are other post translational regulations with the increase of translational nuclear factor "Krupper-like 2 " (KLF-2), important to the transcription of endothelium protecting genes. All these observations have motivated studies which demonstrated in animal models that statins improve endothelial intrahepatic dysfunction, reduce $\mathrm{RVIH}$ and improve the flow mediated by vasodilation of intrahepatic vascularization in response to the ingestion of meals, attenuating the elevation of post prandial GPVH without interference in hepatic flux (ZAFRA; ABRALDES et al., 2004; ABRALDES; RODRIGUEZ-VILARRUPLA et al.,

\section{7; TREBICKA; HENNENBERG et al., 2007).}

The liver is the greatest site of statin action, mainly related to cholesterol synthesis. The blockage in the production of cholesterol also diminishes intermediaries including isoprenoids and acts decreasing oxidized LDL and alpha-TNF. Oxidized LDL is an agonist of endothelin production and when decreased, through inhibition of the Rho/RhoA kinase, allowing the decrease of production and liberation of endothelin-1. Indirectly, promoting the interaction of eNOS with heat shock protein (Hsp 90) allowing the long term activation of eNOS.

Sauerbruch and collaborators (TREBICKA; HENNENBERG et al., 2007) have shown that atorvastatin attenuates hepatic fibrosis in rats submitted to bile duct ligation. In the established cirrhosis, atorvastatin decreased the proliferation and apoptosis of myofibroblastic HSC and the expression of profibrotic kitokines without significative effects in inflammation. Atorvastatin also interferes with the Rho/Rho a kinase, inhibiting and decreasing vascular tone for the complex mechanisms that involve its regulation. The most important conclusion of this study was, then, that atorvastatin can attenuates HSC activation and collagen deposition while in completely established advanced fibrosis, a week of atorvastatin didn't affect collagen content but instead decrease HSC renovation and expression of pro-fibrotic cytokines. These beneficial effects of atorvastatin in animal models need to be confirmed in human beings (TREBICKA; HENNENBERG et al., 2010).

Statins also interfere in caveolin-1 levels negatively regulating its expression and interaction with eNOS, acting in the RhoA/Rho-kinase, inhibiting that passage and favouring eNOS activity(picture 4). When activated, that intracellular signalling route results in unbalance in both RNAm stability and phosphorylation mediated eNOS activation (RAMIREZ; BRICENO et al., 2012). 


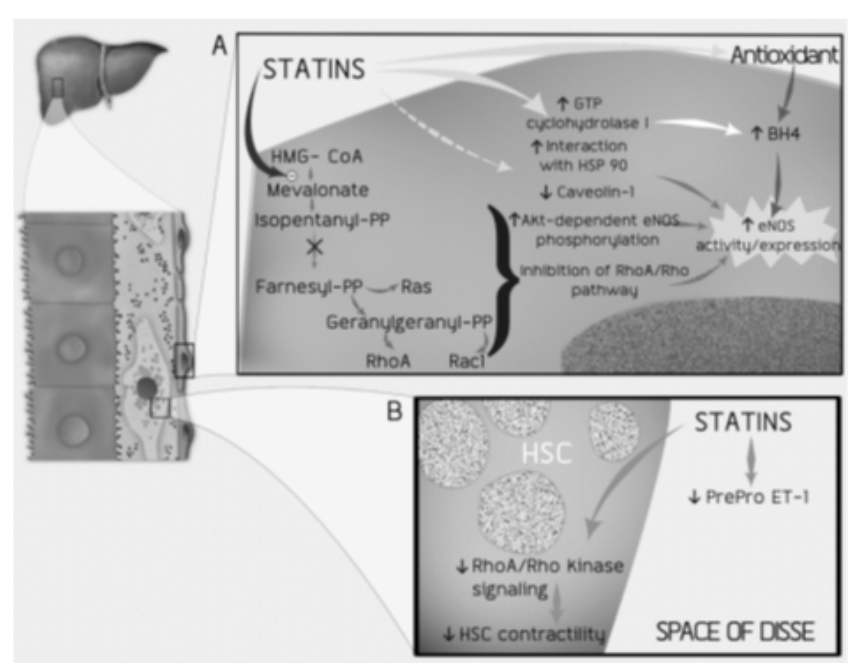

Picture 4. Simvastatins pathways of action (RAMIREZ et al., 2012)

Inflammatory stimulus induces the expression of platelet adherent molecules (VCAM 1 and Icam 1) which recruit immune cells to the vessel wall. These molecules are also targets of simvastatin and atorvastatin that decreasing them, interferes with the inflammatory response cause by monocyite adhesion to the vessel walls (RAMIREZ; BRICENO et al., 2012).

A healthy endothelium produces thrombomodulin and tissue plasminogen activator (tPA) while inflammatory stimulus decreases thrombomodulin and increases pro-clotting factors. Statins reduce major histocompatibility complex class 2 molecule (MHC II) inducing in endothelial cells and as consequence decrease activation of immunological $\mathrm{T}$ cells. Recent studies show that statins stimulate production of endothelium protecting nuclear factors such as "Kruppel-Like factor 2" (KLF-2) and Peroxisome proliferator-activated receptors (PPARs) (JAIN; RIDKER, 2005; MOLLER; GULBERG et al., 1995) .

Zafra and collaborators have shown that simvastatin was capable of increasing hepatic blood flow and atennuating post prandial increase of GPVH. Simvastatin effect was due to the decrease of intrahepatic sinusoidal resistance, laboratorially characterized by NO increase (ABRALDES; ALBILLOS et al., 2009; ZAFRA; ABRALDES et al., 2004).

The future of therapeutics is its individualization, offering à la carte treatment through development of new medications. Cirrhotic portal hypertension is a challenge in this bout.

\section{REFERENCES}

ABRALDES, J.G.; ALBILLOS, A.; BAÑARES,R.; TURNES, J.; GONZÁLEZ, R.; GARCÍA-PAGÁN, J.C.; BOSCH, J. Simvastatin lowers portal pressure in patients with cirrhosis and portal hypertension: a randomized controlled trial. Gastroenterology, v. 136, n. 5, p. 16511658,2009 .

ARROYO, A. G.; IRUELA-ARISPE, M. L. Extracellular matrix, inflammation, and the angiogenic response. Cardiovasc Res, v. 86, n. 2, p. 226-235, 2010.

ARROYO,V.; GINÈS, P.; GERBES, A.L.; DUDLEY, F.J.; GENTILINI, P.; LAFFI, G.; REYNOLDS, T.B.; RINGLARSEN, H.; SCHÖLMERICH, J. Definition and diagnostic criteria of refractory ascites and hepatorenal syndrome in cirrhosis. International Ascites Club.Hepatology, v. 23, n. 1, p. 164-176, 1996.

BAÑARES, R.; MOITINHO, E.; MATILLA, A.; GARCÍAPAGÁN, J.C.; LAMPREAVE, J.L.; PIERA, C.; ABRALDES, J.G.; DE DIEGO, A.; ALBILLOS, A.; BOSCH, J. Randomized comparison of long-term carvedilol and propranolol administration in the treatment of portal hypertension in cirrhosis. Hepatology, v. 36, n. 6, p. 1367-1373, 2002.

BERZIGOTTI, A.; BOSCH, J. Pharmacologic Management of Portal Hypertension. Clin Liver Dis, v. 18, n. 2, p. 303317, 2014.

BERZIGOTTI, A.; GILABERT, R.; ABRALDES, J.G.; NICOLAU, C.; BRU, C.; BOSCH, J.; GARCÍA-PAGAN, J.C. Noninvasive prediction of clinically significant portal hypertension and esophageal varices in patients with compensated liver cirrhosis. Am J. Gastroenterol, v. 103, n. 5, p. 1159-1167, 2008.

BOLOGNESI, M. et al. Splanchnic vasodilation and hyperdynamic circulatory syndrome in cirrhosis. World J Gastroenterol, v. 20, n. 10, p. 2555-2563, 2014.

BOSCH, J. Vascular deterioration in cirrhosis: the big picture. J Clin Gastroenterol, 41 Suppl 3, p. 247-253, 2007.

BOSCH, J. et al. Hepatic endothelial dysfunction and abnormal angiogenesis: new targets in the treatment of portal hypertension. J Hepatol., v. 53, n. 3, p. 558-567, 2010. 
BOSCH, J. et al. The management of portal hypertension: rational basis, available treatments and future options. $\mathbf{J}$ Hepatol, v. 48, Suppl 1, p. 68-92, 2008.

CHENG, J. W. et al. Meta analysis of propranolol effects on gastrointestinal hemorrhage in cirrhotic patients. World J Gastroenterol., v. 9, n. 8, p. 1836-1839, 2003.

DI PASCOLI, M. et al. Resveratrol improves intrahepatic endothelial dysfunction and reduces hepatic fibrosis and portal pressure in cirrhotic rats. J Hepatol., v. 58, n. 5, p. 904-910, 2013.

GARCIA-CALDERO, $\mathrm{H}$. et al. Tempol administration, a superoxide dismutase mimetic, reduces hepatic vascular resistance and portal pressure in cirrhotic rats. J Hepatol., v. 54, n. 4, p. 660-665, 2011.

GARCIA-TSAO, G.; BOSCH, J. Management of varices and variceal hemorrhage in cirrhosis. N Engl J Med., v. 362, n. 9, p. 823-832, 2010.

GARCIA-TSAO, G. et al. Now there are many (stages) where before there was one: In search of a pathophysiological classification of cirrhosis. Hepatology, v. 51, n. 4, p. 1445-1449, 2010.

GONZALEZ, R. et al. Meta-analysis: Combination endoscopic and drug therapy to prevent variceal rebleeding in cirrhosis. Ann Intern Med., v. 149, n. 2, p. 109-122, 2008.

IWAKIRI, Y. Endothelial dysfunction in the regulation of cirrhosis and portal hypertension. Liver Int., v. 32, n. 2, p. 199-213, 2012.

IWAKIRI, Y. Pathophysiology of portal hypertension. Clin Liver Dis., v. 18, n. 2, p. 281-291, 2014.

JAGAVELU, K. et al. Endothelial cell toll-like receptor 4 regulates fibrosis-associated angiogenesis in the liver. Hepatology, v. 52, n. 2, p. 590-601, 2010.

JAIN, M. K.; RIDKER, P. M. Anti-inflammatory effects of statins: clinical evidence and basic mechanisms. Nat Rev Drug Discov., v. 4, n. 12, p. 977-987, 2005.
LAVINA, B. et al. Superoxide dismutase gene transfer reduces portal pressure in $\mathrm{CCl} 4$ cirrhotic rats with portal hypertension. Gut., v. 58, n. 1, p. 118-125, 2009.

LEBREC, D. et al. Propranolol--a medical treatment for portal hypertension?" Lancet, v. 2, n. 8187, p. 180-182, 1980.

LEBREC, D. et al. Propranolol for prevention of recurrent gastrointestinal bleeding in patients with cirrhosis: a controlled study. N Engl J Med., v. 305, n. 23, p. 13711374, 1981.

MATEI, V. et al. The eNOS cofactor tetrahydrobiopterin improves endothelial dysfunction in livers of rats with CCl4 cirrhosis. Hepatolog y, v. 44, n. 1, p. 44-52, 2006.

MATEI, V. et al. Three-day tetrahydrobiopterin therapy increases in vivo hepatic NOS activity and reduces portal pressure in CCl4 cirrhotic rats. J Hepatol., v. 49, n. 2, p. 192-197, 2008.

MCGUIRE, R. F. et al. Role of extracellular matrix in regulating fenestrations of sinusoidal endothelial cells isolated from normal rat liver. Hepatology., v. 15, n. 6, p. 989-997, 1992.

MOLLER, S. et al. Endothelin-1 and endothelin-3 in cirrhosis: relations to systemic and splanchnic haemodynamics. J Hepatol., v. 23, n. 2, p. 135-144, 1995.

MOLLER, S. et al. The management of ascites in cirrhosis: report on the consensus conference of the International Ascites Club. Hepatology, v. 38, n. 1, p. 258-266, 2003.

OPIO, C. K.; GARCIA-TSAO, G. Managing varices: drugs, bands, and shunts. Gastroenterol Clin North Am, v. 40, n. 3, p. 561-579, 2011.

RAMIREZ, G. et al. Statins and portal hypertension: a new pharmacological challenge. Curr Vasc Pharmacol, v. 10, n. 6, p. $767-772,2012$.

REIBERGER, T. et al. Carvedilol for primary prophylaxis of variceal bleeding in cirrhotic patients with haemodynamic non-response to propranolol. Gut, v. 62 , n. 11, p. 16341641, 2013. 
RIPOLL, C. Hepatic venous pressure gradient and outcomes in cirrhosis. J Clin Gastroenterol, v. 41, Suppl 3, p. 330-335, 2007.

RIPOLL, C. et al. Hepatic venous pressure gradient predicts clinical decompensation in patients with compensated cirrhosis. Gastroenterology, v. 133, n. 2, p. 481-488, 2007.

RODRIGUEZ-VILARRUPLA, A. et al. PPARalpha activation improves endothelial dysfunction and reduces fibrosis and portal pressure in cirrhotic rats. J Hepatol, v. 56, n. 5, p. 1033-1039, 2012.

ROSADO, E. et al. Terutroban, a TP-receptor antagonist, reduces portal pressure in cirrhotic rats. Hepatology, v. 58, n. 4, p. 1424-1435, 2013.

SHAH, V. et al. Impaired endothelial nitric oxide synthase activity associated with enhanced caveolin binding in experimental cirrhosis in the rat. Gastroenterology $\mathrm{v}$. 117, n. 5, p. 1222-1228, 1999.

SOLA, E.; GINES, P. Renal and circulatory dysfunction in cirrhosis: current management and future perspectives." J Hepatol, v. 53, n. 6, p. 1135-1145, 2010.

THABUT, D. et al. High-density lipoprotein administration attenuates liver proinflammatory response, restores liver endothelial nitric oxide synthase activity, and lowers portal pressure in cirrhotic rats. Hepatology, v. 46, n. 6, p. 1893-1906, 2007.

TREBICKA, J. et al. Atorvastatin lowers portal pressure in cirrhotic rats by inhibition of RhoA/Rho-kinase and activation of endothelial nitric oxide synthase. Hepatology, v. 46, n. 1, p. 242-253, 2007.

TREBICKA, J. et al. Atorvastatin attenuates hepatic fibrosis in rats after bile duct ligation via decreased turnover of hepatic stellate cells. J Hepatol, v. 53, n. 4, p. 702-712, 2010.

TSOCHATZIS, E. A. et al. New therapeutic paradigm for patients with cirrhosis. Hepatology, v. 56, n. 5, p. 19831992, 2012.
VERBEKE, L. et al. Obeticholic acid, a farnesoid X receptor agonist, improves portal hypertension by two distinct pathways in cirrhotic rats. Hepatology, v. 59, n. 6, p. 2286-2298, 2014.

VOROBIOFF, J. D.; GROSZMANN, R. J. Prevention of portal hypertension: from variceal development to clinical decompensation. Hepatology, v. 61, n. 1, p. 375381, 2015.

ZAFRA, C. et al. Simvastatin enhances hepatic nitric oxide production and decreases the hepatic vascular tone in patients with cirrhosis. Gastroenterology, v. 126, n. 3, p. 749-755, 2004.

ZIPPRICH, A. et al. Prognostic indicators of survival in patients with compensated and decompensated cirrhosis. Liver Int, v. 32, n. 9, p. 1407-1414, 2012.

Recebido em: 23 de maio de 2015 Aceito em: 25 de Agosto de 2015

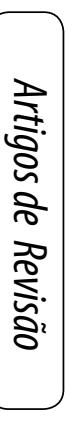

